\title{
European Goniopholididae from the Early Albian Escucha Formation in Ariño (Teruel, Aragón, Spain)
}

\author{
Ángela D. BUSCALIONI ${ }^{*}$, Luis ALCALÁ2, Eduardo ESPÍLEZ² \& Luis MAMPEL ${ }^{2}$
}

\author{
${ }^{1}$ Departamento de Biología, Paleontología. Universidad Autónoma de Madrid. Cantoblanco, 28049 Madrid, Spain; angela. \\ delgado@uam.es \\ ${ }^{2}$ Fundación Conjunto Paleontológico de Teruel-Dinópolis/Museo Aragonés de Paleontología. Avda. Sagunto s/n, 44002 Teruel, \\ Spain; alcala@fundaciondinopolis.org; espilez@fundaciondinopolis.org; mampel@fundaciondinopolis.org \\ * Corresponding author
}

Buscalioni, A.D., Alcalá, L., Espílez, E. \& Mampel, L. 2013. European Goniopholididae from the Early Albian Escucha Formation in Ariño (Teruel, Aragón, Spain). [Goniopholididae europeos del Albiense Temprano de la Formación Escucha en Ariño (Teruel, Aragón, Spain)]. Spanish Journal of Palaeontology, 28 (1), 103-122.

\begin{abstract}
Although goniopholidids constitute the most abundant remains of the Lower Cretaceous record of the Iberian Peninsula crocodilians, few specimens have been found complete enough to provide precise taxonomic determinations. The palaeontological site of Mina Santa María in Ariño (Teruel, Early Albian Escucha Formation) has yielded several neosuchian monotaxic concentrations. The skulls discovered at the Ariño Mine show a character combination linking them to the latter European species. The Ariño skulls share apomorphies with Anteophthalmosuchus hooleyi, Goniopholis willetti (e.g., loss of the transverse frontal crest and of the prefrontal-lachrymal crest, supratemporal fossa larger than the orbit and supratemporal fenestra subequal, among other derived characters). The new taxa, Hulkepholis plotos gen. n., sp. n. and Anteophthalmosuchus escuchae sp. n., are herein erected, and they constitute the most recent record of their
\end{abstract}

\section{RESUMEN}

A pesar de que los restos de goniofolídidos son los más abundantes del registro de cocodrilos del Cretácico Inferior de la Península Ibérica, pocos ejemplares se han descubierto lo suficientemente completos como para proporcionar determinaciones taxonómicas precisas. Las concentraciones monotáxicas de cocodrilos neosuquios descubiertas en la Mina Santa María de Ariño (Teruel, Albiense Temprano de la Formación Escucha) han proporcionado restos craneales, cuya combinación de caracteres los vincula con el clado de los Goniopholididae temporalmente más modernos. Las apomorfías compartidas (ausencia de cresta prefronto-lacrimal y de cresta frontal interorbitaria; fenestra supratemporal subigual a la órbita, siendo las fosas mucho mayores en diámetro, entre otros caracteres derivados) permiten caracterizar los dos nuevos táxones: Hulkepholis plotos gen. n., sp. n. y Anteophthalmosuchus escuchae sp. 
clade in Europe. These sympatric species lived in a coastal marsh system with barrier islands and lagoon.

Keywords: Neosuchia, Goniopholididae, Lower Albian, Oliete sub-basin, Maestrazgo basin, Iberian Peninsula, palaeobiogeography. n. Estas especies simpátricas habitaron en un sistema costero de pantanal con islas barrera y lagoon. Los goniofolídidos de Ariño son especies emparentadas con las formas de Wessex del sur de Inglaterra (Anteophthalmosuchus hooleyi, Goniopholis willetti) y constituyen las formas más modernas del registro del clado en Europa.

Palabras clave: Neosuchia, Goniopholididae, Albiense Inferior, subcuenca de Oliete, cuenca del Maestrazgo, Península Ibérica, paleobiogeografía.

\section{INTRODUCTION}

The goniopholidid neosuchians are one of the most common taxa of the crocodylomoph Mesozoic European record. Goniopholidid-like teeth and osteoderms are dominant elements in fossil assemblages of continental lacustrine, fluviolacustrine, fluvial, freshwater lagoon to shallow offshore environments from Western Europe (Schwarz, 2002; Pouech, 2008; Salisbury \& Naish, 2011). The goniopholidid Iberian record follows this same trend (see Buscalioni, 1986a, 1986b for a historical perspective) and members of the family have been identified in the Kimmeridgian of the Alcobaça Formation (Portugal) (Crespo, 2002; Schwarz, 2002), and throughout the Berriasian to Upper Barremian/Aptian Formations of different Iberian basins: Cameros (Urbión, Golmayo, Castrillo de la Reina and Pinilla de los Moros Formations; Buscalioni, 1986b; Ortega et al., 1996; Fuentes-Vidarte et al., 2003), Maestrazgo (El Castellar, Camarillas, Artoles, Arcillas de Morella, and Forcall Formations; Buscalioni, 1986a; Buscalioni \& Sanz, 1987; Cuenca-Bescós et al., 1999; Ruiz-Omeñaca et al., 2004; Sánchez-Hernández et al., 2007; Sastre García, 2007; Gasulla et al., 2011) and in the south Iberian sub-basin (La Huérguina Formation; Brinkmann, 1992; Buscalioni et al., 2008). However, despite its abundance, this material is fragmentary and composed by isolated, non diagnostic elements. Few Iberian specimens preserving skull elements have provided solid diagnoses as the Guimarota species Goniopholis baryglyphaeus (Schwarz, 2002), while others were tentatively attributed to Goniopholis sp. (Ortega et al., 1996), Goniopholis cf. simus (Buscalioni, 1986a, 1986b), and Goniopholis cf. crassidens (Buscalioni, 1986b; Buscalioni \& Sanz, 1987) (Fig. 1).

Here we present the first evidence of complete articulated goniopholidid skulls from Early Albian Escucha Formation discovered in the locality of Mina Santa María in Ariño (Teruel, Aragón, Spain). The Ariño locality has yielded a rich vertebrate assemblage in which archosaurs are the most abundant fossils (Alcalá et al., 2012). Other isolated goniopholidid elements, of similar age (Lower Albian), have been reported at the nearby locality of Corta Barrabasa (Andorra, Teruel) (Puértolas-Pascual et al., 2012).

A taxonomic revision of the family Goniopholididae has been taking long process since the taxon was erected by Cope in 1875 based on the description of the British Purbeck crocodilian assemblages by Owen in 1842 . The legate of an overflowing number of Goniopholis species (i.e., 22 according to Steel, 1973) was corrected by Salisbury et al. (1999), Salisbury (2002) and recently by Salisbury \& Naish (2011), Andrade \& Hornung (2011) and Andrade et al. (2011). Recent detailed descriptions on the European goniopholidids have revealed that this clade show a higher diversity than previously supposed (Andrade et al., 2011). Two clades have been proposed, one gathering species of the genus Goniopholis (G. simus, G. kiplingi and G. baryglyphaeus) and an unnamed clade in which the upper Barremian to Aptian goniopholidids were assembled. This last clade is defined by three terminal taxa: "Dollo-specimen", "Hulke-specimen" and "Hooleyspecimen". In the revision of the taxonomic status of the crocodilians of the southern England Wealden Supergroup by Salisbury \& Naish (2011), the authors erected the new species Goniopholis willetti for the "Hulke-specimen", and the genus Anteophthalmosuchus for the "Hooleyspecimen" (A. hooleyi). The "Dollo-specimen" has no formal denomination yet. The erection of the scientific name of $G$. willetti, preceding the phylogenetic revision of the family according to Andrade et al. (2011), has resulted in a paraphyletic Goniopholis grouping. This situation should be corrected in further analyses testing the phylogenetic definition of Goniopholis and its sister clade within Goniopholididae on the light of the new discoveries.

Latter contributions have provided a more complex scenario on the goniopholidid diversity. The Ariño assemblage renders crucial in the understanding of the European goniopholidid diversity and biostratigraphic extension during the "mid" Cretaceous. We present a 


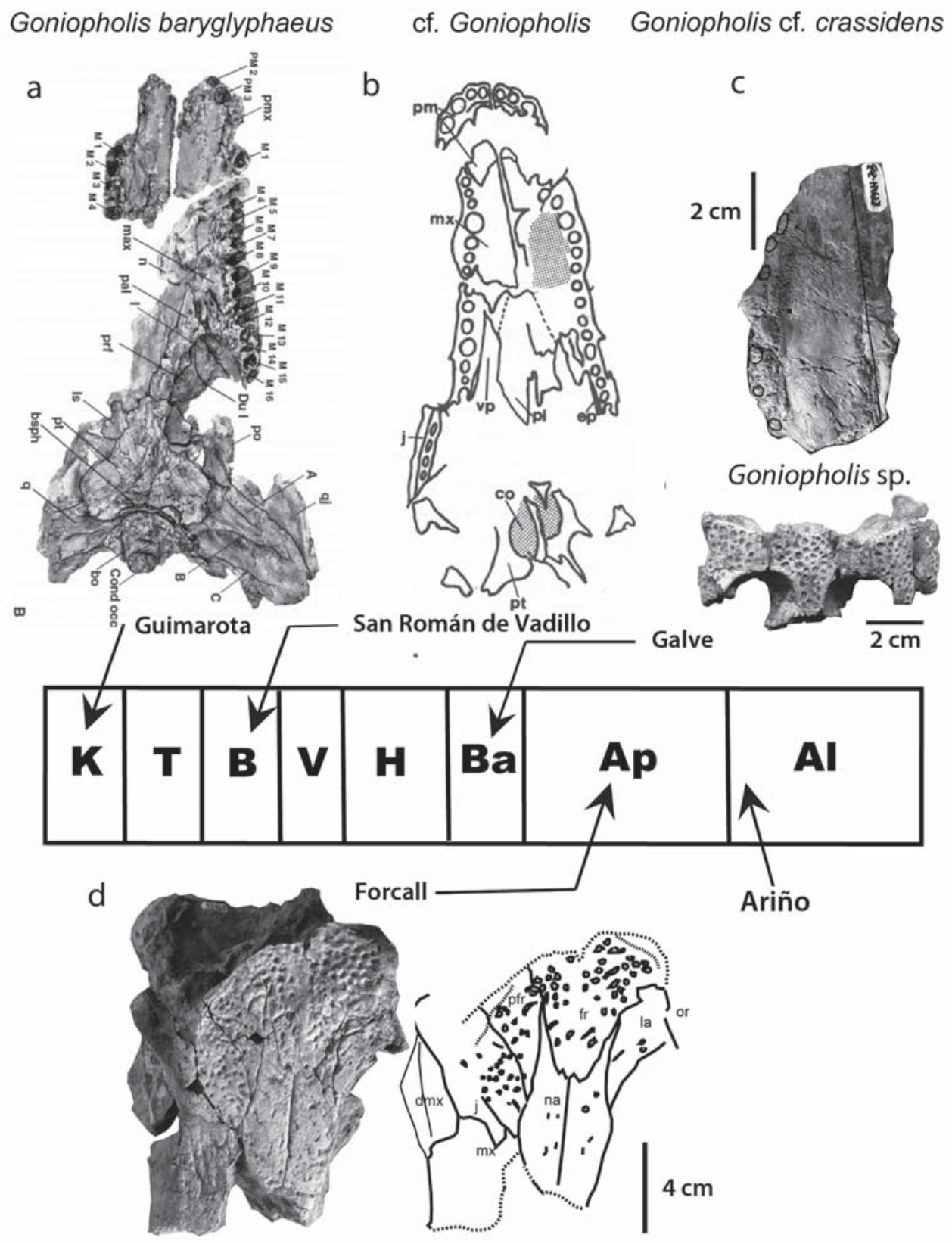

Goniopholis cf. simus

Figure 1. Goniopholididae from the Iberian Peninsula. Their chronostratigraphic record comprises the Kimmeridgian (K), Berriasian (B), Barremian (Ba), Aptian (Ap) and Early Albian (Al). Localities and taxonomic attributions are specified below each specimen. a) Goniopholis baryglyphaeus (Schwarz, 2002), in ventral view. b) The Berriasian Goniopholis sp. from Cameros (Ortega et al., 1996), in ventral view. In the Cameros specimen the lanceolate and wide choana resembles that of G. kiplingi and G. simus, differing from the long and narrow choana of the Ariño specimens. The premaxillo-maxillary suture has a W-shape different to G. simus; and the size of premaxillary teeth (in which the third and fourth are the largest) is similar to G. kiplingi and G. baryglyphaeus differing in this feature from the Ariño specimen. c) Skull material from Galve (Cabezo Santa Bárbara and Rocha-Pelejón, both Lower Barremian in age; Díaz Molina \& Yébenes, 1987). On top, maxillary fragment from the Rocha-Pelejón (RPAH-203), in ventral view. The attribution to G. cf. crassidens (synonymous of $G$. simus, Salisbury, 2002) was based on its wide rostral proportion. On bottom, a skull table in dorsal view from the Cabezo Santa Bárbara (CBP-835) specimen. It was attributed to cf. Goniopholis sp. since the comparison with G. simus and G. crassidens was not definitive (Buscalioni \& Sanz, 1987). d) The Aptian specimen from Castellón (Forcall Formation) (MSB-ref. 39484) attributed to G. cf. simus is based on the scarce rostral ornamentation, the presence of interorbital crest, and the configuration of the sutures between nasal, lachrymal, prefrontal and frontal. The preorbital area shows: the frontal with a truncated anterior-most tip; narrow anterior prefrontal process; and widen lachrymal and jugal. Note: see text for abbreviations. 
preliminary taxonomic determination of three skulls discovered at Ariño. These skulls comprise the sole well preserved material that can be compared with the Wessex (southern England) and Bernissart (Belgium) type species of Goniopholis and Anteophthalmosuchus.

\section{MATERIAL AND PRESERVATION}

The palaeontological research project carried out in a partnership with the mining company SAMCA has identified a Lower Cretaceous outcrop with outstanding bone concentrations of vertebrate fossils from the Early Albian Escucha Formation. These mining operations have exposed an extensive area (15 ha) of a vertebrate bearing stratum that permitting an extensive, ongoing palaeontological salvage program of potentially great significance. The excavations at Mina Santa María, Ariño (Teruel, Spain) are performed following a single fossiliferous level (AR-1) where numerous individualized bone concentrations have been mapped. The site, dated Lower Albian (Alcalá et al., 2012; Tibert et al., in press.) is placed at the Middle Interval with Coal, Lower Sedimentary Succession, Escucha Formation, according to RodríguezLópez et al. (2009). A preliminary examination of the more than five thousand identifiable vertebrate fossils recovered by the end of year 2012 has allowed us to identify numerous species of vertebrates, specifically dinosaurs (including a new genus and species of ornithopod -Proa valdearinnoensis [McDonald et al., 2012]-, thyreophorans and theropods), turtles, crocodiles and fishes (both bony and cartilaginous), as well as coprolites, plant remains (logs, plant fragments, palynomorphs, amber), bivalves, gastropods and ostracods (Alcalá et al., 2012).

Although the age and genesis of the classic locality of Bernissart (Belgium) and Ariño are not comparable, fossil preservation shares some similarities associated with pyrite oxidations. The high proportion of iron bisulphide microcrystals in Ariño's fossils, and its instability (even in humid depressed conditions) will affect their integrity in short-term. In fact, the mechanisms directly or indirectly linked to the pyrite oxidation are often responsible for the bursting of the bone structure, having a disastrous effect on bone conservation (Leduc, 2012). The safeguarding techniques tested in Bernissart fossils have proven to be inefficient to prevent the destructive processes, but in some cases they have partially slowed them down (Leduc, 2012).

Ariño's vertebrates follow two types of taphonomic assemblages: 1) as disperse elements all over the fossiliferous layer. Here, crocodilian osteoderms and turtle scutes result the most common elements; and 2) as monotaxic (occasionally bitaxic) concentrations of articulated or semi-articulated fossils. This taphonomic pattern is recurrent and homogeneous in the sampled horizon AR-1 (Fig. 2). The crocodyliform assemblage is the most frequent ( $66 \%$ of the concentrations found), with $23 \%$ of the sampled crocodyliform concentrations composed by postcranial and cranial remains. Crocodyliforms were found associated with turtles mostly (36 cases of 64 assemblages), or phytophagous dinosaurs (14 cases), or carnivorous dinosaurs (11 cases).

The studied goniopholidid assemblage is composed by cranial and postcranial elements. The concentration \#62 is composed by a skull lacking premaxillae (AR-13422), and by two dentary fragments (AR-1-3423 and AR-1-4676) from the same individual. The concentration is also composed by postcranial isolated elements, such as paramedial not keeled osteoderms (subrectangular in shape, wider than longer, with a flat strongly ornamented dorsal surface bearing a strong anterolateral projection); amphicoelous vertebrae (centra with a neat and wide neurocentral suture, and a medially compressed body); and appendicular elements (girdle and limb fragments). AR-13422 is dorsoventrally compressed and laterally sheared; it bears a biting mark at the maxilla. The concentration \#56 is composed by a completely articulated skull (AR-12045), lacking the mandible. The skull is distorted; bones are inwardly curved with important cracks at the ventral and occipital regions. The concentration \#37 corresponds to a partial articulated skull (AR-1-1097) divided in two parts, maxilla and skull table. Other disarticulated skull elements are a left quadrate and a posterior fragment of the right mandible. The skull preserves sutural details but it is dorsoventrally compressed.

In the studied material there is any evidence of bone abrasion and erosion, indicating that carcasses were produced close where they were buried (autochthonous). However, skeletal disarticulations including skull detaching suggest at least a short subarial exposure previous to burial enhancing disintegration and disarticulation. In accordance with their habitat these palaeobiological entities should be considered demic (i.e., living in the ecosystem were they were produced).

\subsection{Abbreviations}

Institutional abbreviations: AR, Ariño collection housed at Museo Aragonés de Paleontología (Fundación Conjunto Paleontológico de Teruel-Dinópolis) in Teruel; BMNH, British Museum Natural History, London; IRSNB, Institut Royal des Sciences Naturelles de Belgique, RPAH, Rocha Pelejón, Herrero collection in Galve; CBP, Cabezo Santa Bárbara, Universidad Autónoma Unidad de Paleontología collection; MSB, Museo del Seminario de Barcelona.

Anatomical abbreviations: A-B, quadrate crests; an, angular; bo, basioccipital; bsph, basisphenoid; con occ, condyle occipital; cqp, cranioquadrate passage; co, choana; de, dentary; dmx, maxillary depression; ect, ectopterygoid; 


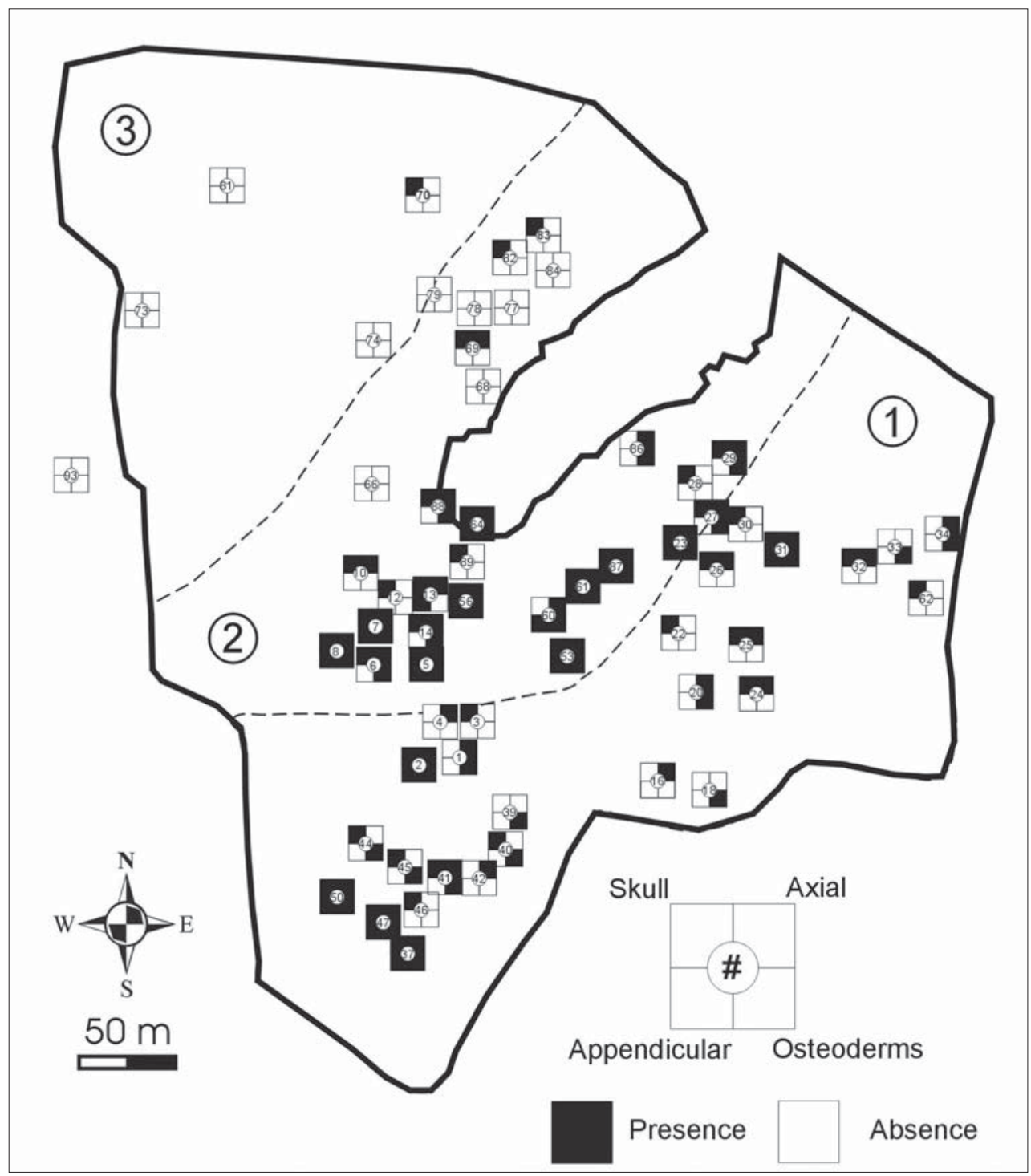

Figure 2. Map of the unearthed concentrations with crocodylomorphs (data updated on December 2012). Notice how the qualitative analysis of the preserved skeletal elements is estimated (blank squares: concentrations not excavate yet). Only three concentrations (AR-1/63, AR-1/91 and AR-1/98) are outside of the outlined area. 1. Area already covered area with mine dumps 2. Fully sampled and exposed fossiliferous level. 3. Fossiliferous level exposed but not sampled yet.

ect-pt, ectopterygoid-pterygoid contact; exo, exoccipital; exo r, exoccipital rim; fm, foramen magnum; fo, foramen; fo ae, foramen aereum; fo eus med, medial Eustachian foramen; fi, foramen incisivum; fr, frontal; j, jugal; la, lachrymal; la c, lachrymal crest; 1t, laterosphenoid; mx, maxilla; na, nasal; or, orbit; or n, orbital anterior notch; pa, parietal; pal, palatine; pab, palpebral; pfr, prefontral; pm, premaxilla; pn c, perinarial crest; po, postorbital; po ap, postorbital anterior projection; po pab, postorbital palpebral; pocc, paraoccipital; pt, pterygoid; q, quadrate; qj, quadratojugal; qj sp, quadratojugal spine; r, rim; rec ot, external otic recess; s, sulcus; stf, supratemporal fenestra; sq, squamosal, su, surangular.

\section{THE ARIÑO GONIOPHOLIDIDAE ASSEMBLAGE}

The revision on the phylogenetic relationships of the family Goniopholididae including a significant number of species of Mesoeucrocodylia has provided details on the character definitions and their evolutionary transformations (Andrade et al., 2011). The European Goniopholididae consists of two clades, one relates the species of the genus Goniopholis (G. simus, G. kiplingi and G. baryglyphaeus) while the other clade comprises stratigraphically the latest (Late Barremian to Aptian) goniopholidids, uniting "Dollo's" + "Hooley's" specimens as sister group to the "Hulke-specimen". Each major clade is rather well 
supported by a set of unambiguous apomorphies. The three skulls from Ariño show the characteristic combination of features diagnostic of the family Goniopholididae, of which the presence of a maxillary fossa, formed by a depressed lobulated area at the level of the maxilla, jugal and lachrymal, is a clear autapomorphy. More specifically, the individuals share the apomorphies that diagnoses the triad of the latest European goniopholidids: the loss of prefrontal-lachrymal crest dorsal to the orbit, and of the transverse frontal crest; the supratemporal fenestra is subequal to the orbit, whereas the fossa is larger than the orbit; lateral process of the frontal arched laterodorsally with palpebral and postorbital curved dorsally; posterior ramus of jugal subcircular to subpolygonal in cross section; ventral margin of the jugal level with the posterior ramus; palatal ramus of maxilla takes part in the anteromedial border of suborbital fenestra; the anterior palatine process of palate is evidently longer than wider.

Recent osteological revisions on the European goniopholidid skulls focus their specific differences on the periorbital morphology (Andrade \& Hornung, 2011). The periorbital morphology, as described by these authors, is compound by the arrangement and disposition of the orbit, the palpebrals, the jugal, the lachrymal and the postorbital. The configurations of the periorbital area in "Dollo's" and "Hooley's" specimens are similar. According to Andrade et al. (2011) both taxa constitute a node sharing features such as: the dorsal component of the orbit; prefrontals very long, reaching the posteromedial borders of the orbit; jugal only forms a narrow band of bone below the orbit; palpebrals are small, robust, and rectangular or very elongated. Other shared apomorphies concern the shape of the supratemporal fossa (circular), and the very long and robust condition of the preorbital anterolateral process shielding the anterolateral section of the orbit; the nasopharyngeal duct has a deep sulcation exposed at the palatal surface. The periorbital region of the "Hulke-specimen" differs in the interorbital area having a jump-like frontal ridge; a large palpebral, triangular in shape; elongated lachrymal; the shortness of the posterior process of the prefrontal; the inclination of the postorbital bar; and the absence of an elongated anterolateral postorbital process shielding the orbit laterally (Andrade \& Hornung, 2011).

The Ariño goniopholidids are herein compared to unveil major differences among specimens and with other goniopholidids. We centre the description on the rostral shape, the periorbital region and skull table, and we include other relevant parts of the skull as the pterygoidean complex and the mandible when preserved.

\section{SYSTEMATIC PALAEONTOLOGY} 1988)
NEOSUCHIA (sensu Benton \& Clark, 1988)

Family Goniopholididae Cope, 1875

Unnamed Clade (sensu Andrade, Edmonds, Benton \& Schouten, 2011)

Goniopholididae indet.

(Figs 3, 4a; Table 1)

\section{Description.}

\section{Skull}

The skull AR-1-3422 combines a set of features shared with the clade "Dollo-specimen" + "Hooley-specimen" sensu Andrade et al. (2011). The individual age of AR1-3422 corresponds to a subadult animal (sutures are clearly visible). This makes the comparison with the adult specimen Anteophthalmosuchus hooleyi (Salisbury \& Naish, 2011) difficult. The maxillary ornamentation differs from the skull table, being composed by irregular bumps and pits, which are not so enlarged in the specimen as in Anteophthalmosuchus hooleyi, but more similar to that of the "Dollo-specimen". The length of the postorbital region (from the anterior tip of the orbit to the quadrate articulation) is equivalent to the rostral length excluding the premaxilla. Its relative width at the level of the $5^{\text {th }}$ maxillary tooth is $40 \%$ corresponding to a moderate rostral length.

The rostral contour has a premaxillo-maxillary compression at the notch and two lateral and vertical waves (one at the level of the $6^{\text {th }}$, and a second not so pronounced at the level of the $12^{\text {th }}$ tooth). The largest maxillary teeth are $4^{\text {th }}$ and $5^{\text {th }}$. Each maxilla bears $19-20$ teeth. The maxillary depression is placed in front of the suborbital fenestra, and it is longer than wide. The depression is formed by three lobes; the posterior lobe faces anteriorly, and the middle one is dorsally displaced. The posterior lobe level the anterolateral orbital contour.

The palatal view preserves the premaxillo-maxillary suture. The maxilla projects an anteromedial process towards the premaxilla. The pits of mandibular teeth are positioned lingual and in interalveolar spaces; medial to the $10^{\text {th }}$ up to $12^{\text {th }}$ alveoli, these pits are deep. Medial to the posterior alveolar series vascular foramina are wide. The posterior maxillary teeth have a medial platform. The anterior tip of the ventral projection of the ectopterygoid is short and located posterior to the alveolar series. The maxilla sends a lateral posterior projection to the suborbital fenestra that expands anteromedially. The anterior palatine process exceeds the palatal fenestra. The fenestra is very long, corresponding to $50 \%$ of the skull length (excluding the premaxilla). The palatines are straight at the interfenestral area, and bulge slightly posteriorly. There is a median sulcus between palatines. Part of the left pterygoid is preserved; the bone forms the posteromedial border of the palatine fenestra. The palatines participate 

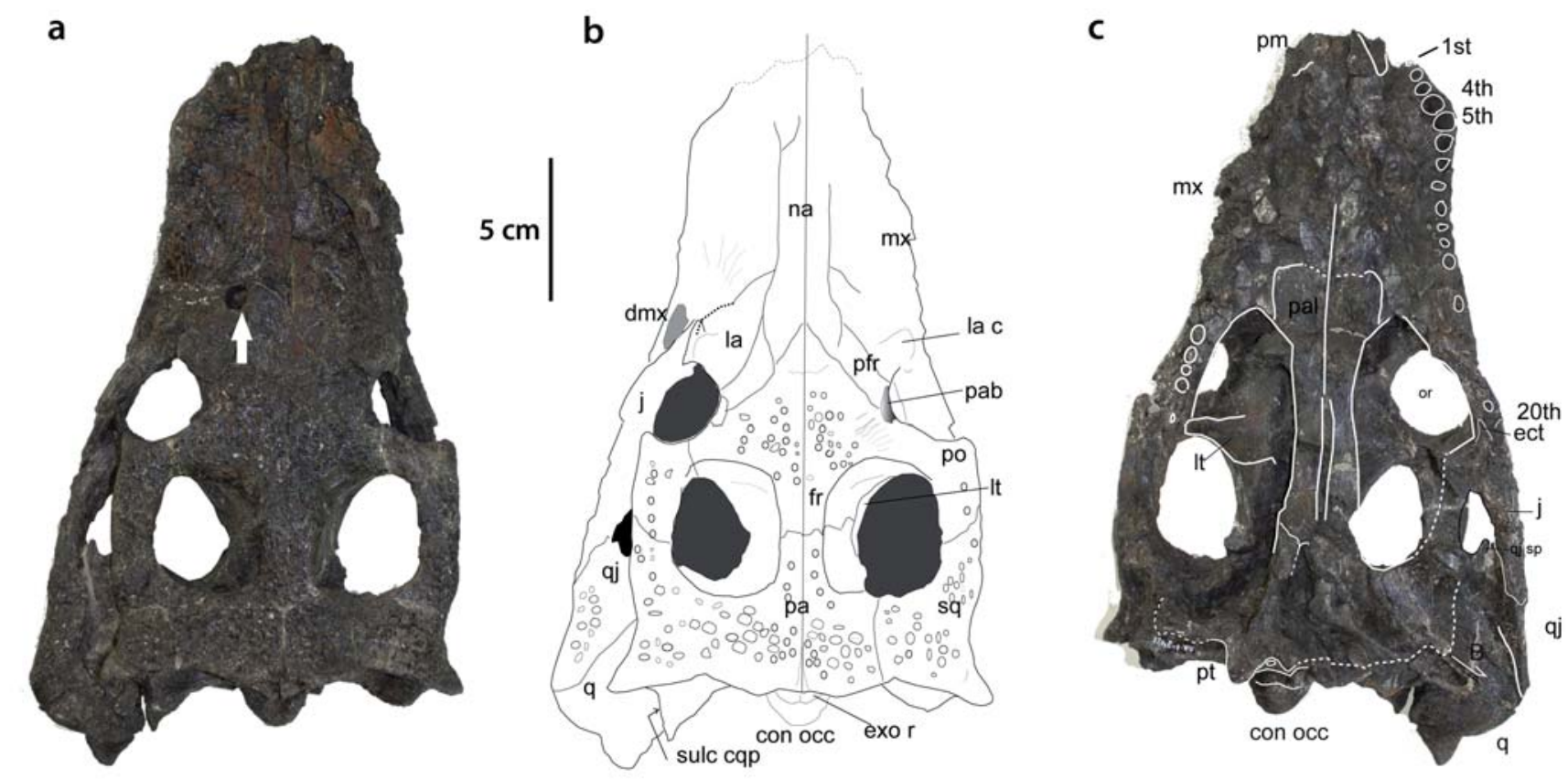

Figure 3. Specimen AR-1-3422 from the Lower Albian of Mina Santa María, Ariño (Teruel Province), Escucha Formation. a-b) Specimen in dorsal view, photograph and schematic interpretation. Notice at the maxilla an isolated circular perforation, probably a biting mark. The specimen is dorsoventrally compressed and distorted. c) Photograph in ventral view. Note: see text for abbreviations.

in the anterior choanal border. The anterior choanal border is located cranial to the posterior margin of the palatal fenestra.

The preorbital region of AR-1-3422 lacks an interorbital crest on the wide dorsal skull surface. The sculpture at this part consists of radiating ridges from the orbital notch towards the maxilla. The orbit is subcircular in shape, and its dorsal contour is neat. The orbit has an anterior long recess where the lachrymo-jugal contacts. The lachrymal is prominent at the anterior orbital border, a similar condition occurs in the "Dollo-specimen". The lachrymal prominence overhangs the orbital recess. A tiny foramen is inset the lachrymal notch. The anterior process of the jugal is short and extends in front of the orbital recess. The jugal forms the laterodorsal orbital margin forming an elevated crested profile. The posteromedial right orbital edge shows a sutural scar for a palpebral bone. This tiny subrectangular palpebral is in articulation at the left orbit. The prefrontal is posteriorly elongated and reaches the palpebral posterior suture. The suture between the prefrontal and lachrymal is clear, and delimited by an incision. The frontals form part of the posterior orbital margin.

The anterior frontal process is triangular in shape. The lachrymal broadly contacts the nasal in its posterior third. The jugal is a long and narrow bone, it overlays the maxilla with an extended sutural contact. The prefrontal is a narrow bone and has a curved convex suture with the
Table 1. Skull measurements in $\mathrm{mm}$. The resulting measures are affected by preservation (flattening, and distortions by curving).

\begin{tabular}{|c|c|c|c|}
\hline Skull measurements & AR-1-3422 & $\begin{array}{c}\text { AR-1-2045 } \\
\text { H. plotos }\end{array}$ & $\begin{array}{l}\text { AR-1-1097 } \\
\text { A. escuchae }\end{array}$ \\
\hline $\begin{array}{l}\text { Skull length } \\
\text { (excluding premaxilla) }\end{array}$ & 198 & 320 & - \\
\hline $\begin{array}{l}\text { Length from the } 1^{\text {st }} \\
\text { maxillary tooth to the } \\
\text { anterior border of the } \\
\text { suborbital fenestra }\end{array}$ & 100 & 155.5 & - \\
\hline $\begin{array}{l}\text { Width of the } \\
\text { interorbital space }\end{array}$ & 80 & 50 & - \\
\hline $\begin{array}{l}\text { Skull width at } 5^{\text {th }} \\
\text { alveoli }\end{array}$ & 90 & 65 & 100 \\
\hline $\begin{array}{l}\text { Width of the } \\
\text { quadrate condyle } \\
\text { including the } \\
\text { quadratojugal } \\
\text { extension }\end{array}$ & 38 & 60 & 62 \\
\hline $\begin{array}{l}\text { Skull table length: } \\
\text { postorbital to } \\
\text { parietal posterior } \\
\text { margin }\end{array}$ & 75 & 11 & - \\
\hline $\begin{array}{l}\text { Mid width of the } \\
\text { skull table }\end{array}$ & c. 14 & 11.4 & 18 \\
\hline
\end{tabular}


frontal. Rostrally, the prefrontal ends in an acute process. Ventrally the prefrontals extend transversally at the level of the prefrontal pillars reaching the lachrymals, and leaving a narrow through between the suborbital fenestra and the maxillary sinus.

The skull table is characterized by is relatively narrow anterior and lateral bars (subequal to less than the intertemporal bar). The supratemporal fossae are wide, and the supratemporal fenestra is of subequal size to the orbit. The fossa is subcircular in shape, with a curved lateromedial margin. Parietals are unfused at the skull table. The frontals form part of the anteromedial border of the supratemporal fossa. At that area the frontals are laterodorsally expanded. The laterosphenoid has a transverse anterior edge, and forms the floor of the supratemporal fossa generating a sharp flatten rim. The parieto-frontal suture is placed at midlength of the fenestra, and it has a straight suture with a mid posterior peak. The posterior projection of the squamosal surpasses the paraoccipital process and is laterally directed. The squamosal-postorbital suture divides dorsally the cranial table in two unequal portions with the squamosal twice as long. The squamosal suture is anterolaterally directed. Laterally the squamosal projects an anterior process that reaches the posterior dorsal edge of the postorbital bar. The anterior border of the postorbital is transverse, and anterolaterally projects a protuberance (broken at the tip).

The infratemporal fenestra faces laterodorsally. At the infratemporal fenestra the section of the jugal is rounded to subpolygonal. The jugal bar is inset, and placed at a depressed platform formed by a long medial extension of the jugal and the ectopterygoid. The bar is not fully preserved, but dorsally it is set below the postorbital anterior expansion. The jugal sutures the quadratojugal anterior to the caudolateral border of the infratemporal fenestra, and extends posteriorly in oblique contact. The suture between the jugal and quadratojugal is ventrally exposed, showing the long posterior jugal process that bends rostrally to enter into the infratemporal fenestra. The quadratojugal projects into a short and stout spine. The quadratojugal and quadrate area is dorsally broad and long. The area has a peculiar unsculptured depressed surface at the otic area with a dorsoventrally low recess at the quadrate. As in other European goniopholidids the cranio-quadrate passage is opened forming a lateral sulcus running ventral to the paraoccipital process and dorsal to the quadrate surface, in which the squamosal lateroventral lamina does not suture with the dorsal surface of the quadrate.

The occipital area (Fig. 4a) is characterized by the relative low quadrate articulation. The dorsal quadrate surface has a mid dorsal crest, delimiting its medial convex contour. The quadrate articulation has a ventrally twisted medial condyle. The ventral surface of the quadrate has a developed crest $\mathrm{B}$ for the attachment of the mandibular a
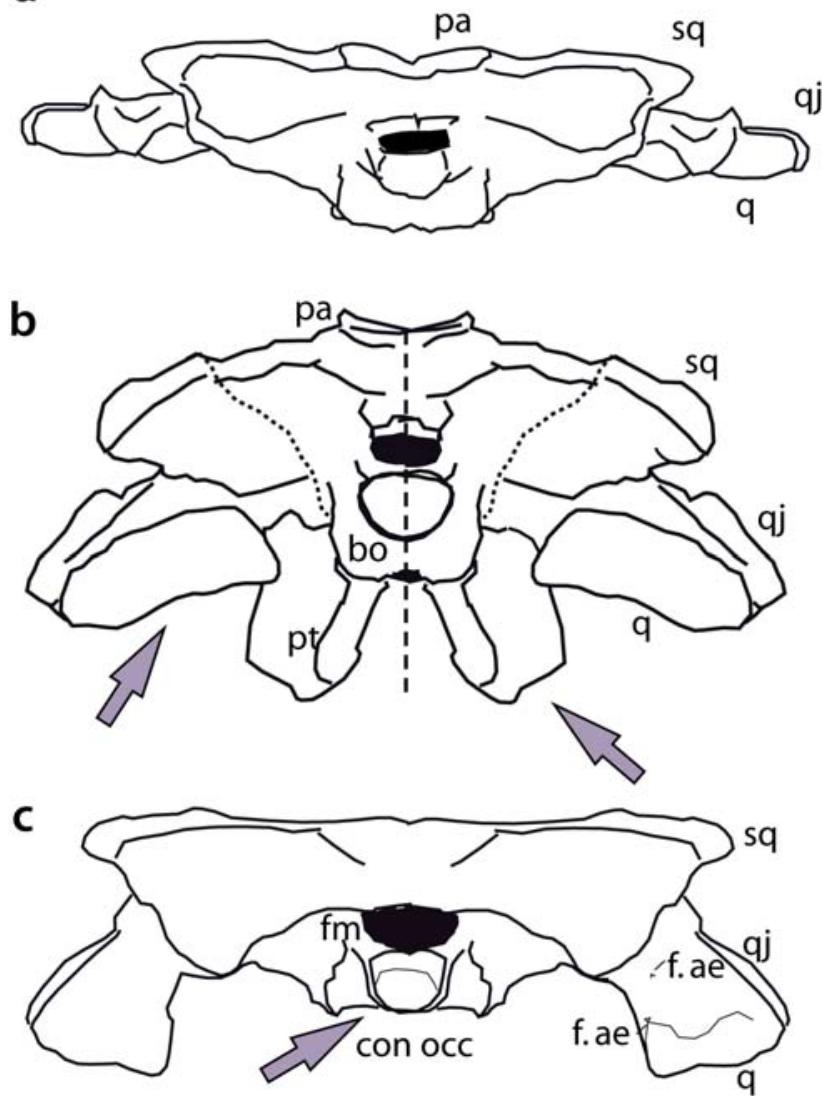

Figure 4. Comparison of the Ariño's goniopholidids in occipital view. All specimens scaled to the quadrate-quadrate baseline. Grey arrows point to the main differences found: squamosal lobe (sq); basioccpital (bo); pterygoid (pt); quadrate (q) and occipital condyle (con occ). a) AR-1-3422 is an undetermined species of the European "mid" Cretaceous lineage. b) AR-1-2045 corresponds to Hulkepholis plotos gen n., sp. n.; the basioccipital is high, and the quadrate articulation is lateromedial and dorsoventrally developed. c) AR-11097 corresponds to Anteophthalmosuchus escuchae sp. n. Notice how the occipital condyle lengthens posteriorly showing a small articular diameter regarding the foramen magnum. The specimen bears two foramina aereum (f. ae). Note: see text for abbreviations.

adductor. The basioccipital is dorsoventrally short but laterally expanded. The ratio between quadrate articulation width and the mid occipital width (mid Eustachian canal to lateral quadrate condyle) is 3.7 .

\section{Mandible}

Two disarticulated fragments of dentaries with eighteen alveoli and teeth in situ were preserved. The dentary when reconstructed has a spatulate anterior outline, with the third tooth almost in line with the first and second, and the fourth posterior to the third. The symphyseal area is massive in 
relation to the dentary ramus, and the lateral profile of the dentary symphysis is elevated at the third and fourth teeth. The set of vascular foramina placed medial to the alveoli are wide. Third and fourth alveoli are confluent and have twice the diameter of the $6^{\text {th }}$ to $9^{\text {th }}$ alveoli, the alveolar diameter increase from the $10^{\text {th }}$ on, forming a peak at the $11^{\text {th }}$ and $12^{\text {th }}$. The alveoli have thin interalveolar spaces. In dorsal aspect the symphyseal area extends to the fifth to sixth alveoli. At midlenght, the dentary is deep and has a quadrangular cross-section. The Meckelian canal is centred and reaches the level of the seventh alveoli. The dentary of AR-1-3423 differs from G. simus (Salisbury et al., 1999; and BMNH-3230 formerly related to G. crassidens) in the anterior outline of the mandibular edge that includes the $4^{\text {th }}$ alveolus, and the wider interalveolar space of the German and British species, so that the distance between the anterior teeth results in a relatively broader and longer symphyseal area. Although these dentary features are similar in G. baryglyphaeus (Schwarz, 2002) and in AR-1-3423, the Guimarota Goniopholis has a peak at the fourteenth alveolar position of the dentary.

Genus Hulkepholis gen. $\mathrm{n}$.

(Figs 4b, 5; Table 1)

Type species. Hulkepholis (=Goniopholis) willetti (see Salisbury \& Naish, 2011; figs 24.2-24.4). Related species: Hulkepholis plotos sp. n., Lower Albian, Ariño, Teruel, Spain.

Derivatio nominis. In honour of John Whitaker Hulke (1830-1895) who described the specimen BMNHB 001876 in 1878 (Hulke, 1878).

Holotype. BMNHB 001876, a nearly complete skull, Salisbury \& Naish (2011; figs 24.2-24.4).

Diagnosis. Hulkepholis shares with Anteophthalmosuchus the following autapomorphies: the loss of prefrontallachrymal crest, dorsal to the orbit, and of the transverse frontal crest; the supratemporal fenestra is subequal to the orbit, whereas the fossa is larger than the orbit; lateral process of the frontal arched laterodorsally with palpebral and postorbital curved dorsally; posterior ramus of jugal subcircular to subpolygonal in cross section; ventral margin of the jugal level with the posterior ramus; palatal ramus of maxilla takes part in the anteromedial border of suborbital fenestra; the anterior palatine process of palate is evidently longer than wider. Hulkepholis is distinguished from Goniopholis and Anteophthalmosuchus in the following combination of characters: skull with a long and narrow rostrum (longirostral, 20-25\% maximum width at the fifth maxillary alveoli of rostral lenght), premaxillary teeth being the $5<4<3<2$, narrow and reduced incisive foramen, presence of an interorbital hump, squamosal lobe short with a rounded boss, large and triangular palpebral, exclusion of the frontal at the orbital contour, parietals almost fused (shared with G. simus), postorbital as long as the squamosal at the dorsal surface of cranial table, prefrontal divides the posteriormost extend of nasals (not exposed in $H$. plotos sp. n.); developed rostral tuberosity on the postorbital bar.

Type locality. Cuckfield, West Sussex (unknown exact location), Grinstead Clay Formation, United Kingdom.

Stratigraphical distribution. Valanginian to Lower Albian.

\section{Hulkepholis willetti Salisbury \& Naish (2011)}

Holotype. BMNHB 001876, a nearly complete skull, Salisbury \& Naish (2011; figs 24.2-24.4).

Diagnosis. Choana midway between palatines and pterygoid, absence of postorbital palpebral.

Type locality. Cuckfield, West Sussex (unknown exact location), Grinstead Clay Formation, United Kingdom.

\section{Hulkepholis plotos $\mathrm{sp} . \mathrm{n}$.}

(Figs 4b, 5; Table 1)

Derivatio nominis. From the Greek $\pi \lambda$ otó $\varsigma$, the drifter.

Holotype. AR-1/56, a partial skeleton deposited at Museo Aragonés de Paleontología/Fundación Conjunto Paleontológico de Teruel-Dinópolis (Teruel, Spain), composed by skull (AR-1-2045), 3 vertebrae (AR-1-2048, AR-1-4859, AR-1-4860), a rib (AR-1-2046), a metapodial (AR-1-2048), and 3 osteoderms (AR-1-2049, AR-1-4861, AR-1-4862).

Diagnosis. Choana with the anterior edge posterior to the palatal fenestra edge, enclosing most of the choanal aperture within the pterygoid, the basioccipital lateral tubera pendulous extending ventral to the Eustachian medial foramen, the postorbital palpebral projecting with an anterolateral wide lamina towards the mid orbit, expanded articular quadrate that is wider than the mid rostral width at the suborbital fenestra.

Type locality. Site AR-1, Mina Santa María, Ariño, Teruel Province, Spain.

Stratigraphical distribution. Middle Interval with Coal, Lower Sedimentary Succession, Escucha Formation (Rodríguez-López et al., 2009), Lower Albian (Alcalá et al., 2012, Tibert et al., in press.). 
Description. The skull AR-1-2045 has the combination of features of the "Hulke-specimen" (Andrade \& Hornung, 2011) recently described as Goniopholis willetti (Salisbury $\&$ Naish, 2011). The rostral ornamentation is profuse and dense, configured by ridges and occasional subcircular pits. The hump-like interorbital ridge might be present although it is not so evident since this area is deformed and fractured in the specimen. The rostrum is elongate and rather narrow, and comprises $59 \%$ of the skull length (excluding the premaxilla), while the relative width to the rostral length at the level of the fifth maxillary tooth is $22 \%$. The maxillary contour presents an anterior lateral to vertical wave up to the $6^{\text {th }}-7^{\text {th }}$ teeth, and a second one better exposed laterally at the $11^{\text {th }}$ tooth. In lateral view, the maxillary alveolar border is unornamented posterior to the $6^{\text {th }}$ alveolus. The maxillary depression is longer than it is wide, and its posterior contour placed at the level of the suborbital fenestra. The maxillary depression has 3 or more widen lobes separated by uncompleted ridges. The anterior premaxillary border is straight and somehow depressed. The premaxilla shows the goniopholidid T-shape although their lateral borders do not surpass the maxillary ones. The anterior band of the premaxilla is deeply verticalized, and the external nare is unique and faces dorsally. The nares are subcircular in shape. The perinarial fossa has verticalized marginal walls. The fossa spread ventrally forming a narial floor. The nares have a perinarial dorsolateral crest ending posteriorly in a knob. Nasals in Hulkepholis (=Goniopholis) willetti do not enter the nares. In AR-1-2045 the area is deformed and downturned forcing the anterior projection of nasals. Nonetheless, the premaxillary mid suture posterior to the nare is partially exposed. The premaxillo-maxillary suture is posteriorly projected reaching the level of the secondthird maxillary tooth. Nasals have parallel sides, although they widen posteriorly forming a curved lateral contour.

The palatal view preserves the premaxilo-maxillary suture placed at the level of the first maxillary tooth, projects its anteriormost tip towards the premaxilla. Ventrally the premaxilla bends at the level of the $4^{\text {th }}$ alveolus leaving a wide notch laterally. The premaxilla bears 5 alveoli although the fifth, which is posterolateral placed, is almost completely reduced. The size of the premaxillary teeth is $5<4<3<2$. The foramen incisivum is a slit like almost closed fenestra. A deep pit for the mandibular tooth is placed lingual in between the first and second, and a second pit is placed lingual to the third in the premaxilla. Each maxilla bears 23-24 alveoli. The interalveolar space is wide (as wide as the alveolar diameter) and subequal, except for the rear maxillary teeth. There are two relevant pits in the maxilla, one placed posterior to the $7^{\text {th }}$ and the other placed between the $8^{\text {th }}$ and $9^{\text {th }}$ alveoli. Pits for reception of mandibular teeth are interfingered along the maxilla (between alveoli). The opening of the trigeminal foramen is medial to the $13^{\text {th }}$ alveolus. The posterior maxillary series has a medial shelf. The ectopterygoid anterior projection is short and rounded, and it is placed medial to the last maxillary alveolus. Palatines are straight and they are prolonged beyond the palatal fenestra forming a lobate (round) suture. The palatine bar widens posteriorly. The pterygoids extend along the skull table length. They are formed by a flat lamina with a thick lateral wing. The ectopterygoid contacts the pterygoid rostrally and does not reach the posterior pterygoid margin. The choana is posteriorly placed; its anterior border at the level of the posterior margin of the suborbital fenestra. It is formed by two narrow and long openings divided by a thick septum. The palatines are involved in the formation of the anterior part of the choana, and they have two medial short ventral projections to the mid septum. Laterally the pterygoids have a concave posterior surface. The posterior pterygoid lamina folds medially, exposing a vertical strand of bone. This fold lies anterior to the basioccipital tubera, leaving a wide space where the Eustachian canal opens. The contact leaves a neat suture between the basioccipital and the pterygoids with no apparent ventral exposition of the basisphenoid.

The periorbital region is characterized by the orbit, which is surrounded by a prominent thick dorsally turned border. This border has a sutural scar for a palpebral extended from the posteromedial border to the medial lachrymal edge. This palpebral is not preserved (Fig. $5 \mathrm{c})$. The postorbital itself shows a sutural anterior border where a palpebral sets avoiding a direct contact of the frontal at the posterior orbital border, thus, being the prefrontal in contact with the postorbital ventral to the orbit. The postorbital is anteriorly cupped and a dorsally protuberant palpebral covers this space. The suture between the postorbital and its palpebral is exposed even laterally. This palpebral curve laterally forming the anterolateral extension of the postorbital process that prolongs towards the lateral contour of the orbit. In $H$. willetti this process is described as rostral tuberosity. This rostral tuberosity is also present in AR-1-2045 specimen at the postorbital bar. However, the development of the process exceeded this condition, and differs from that of AR-1-1097 and $H$. willetti in its robustness because its ventral margin extends ventral to the squamosal lateral shelf. The stout postorbital tip bends ventrally and reaches the mid-lateral orbital contour as in Ariño. The lachrymal presents an anterior deep and narrow recess at the orbital edge. The jugal forms a thick and deep lateral orbital contour but without an elevated border. Lachrymal and prefrontal sutures and their contacts with nasals are obscured.

The cranial table contains long subquadrangular supratemporal fossae. The supratemporal fossa is twice longer than the orbital diameter, although the fenestra is subequal or smaller than the orbit. The anterior and lateral bars of the skull table are wider than the intertemporal bar. The squamosal-postorbital suture divides the cranial table into two subequal portions. The postorbital has an 

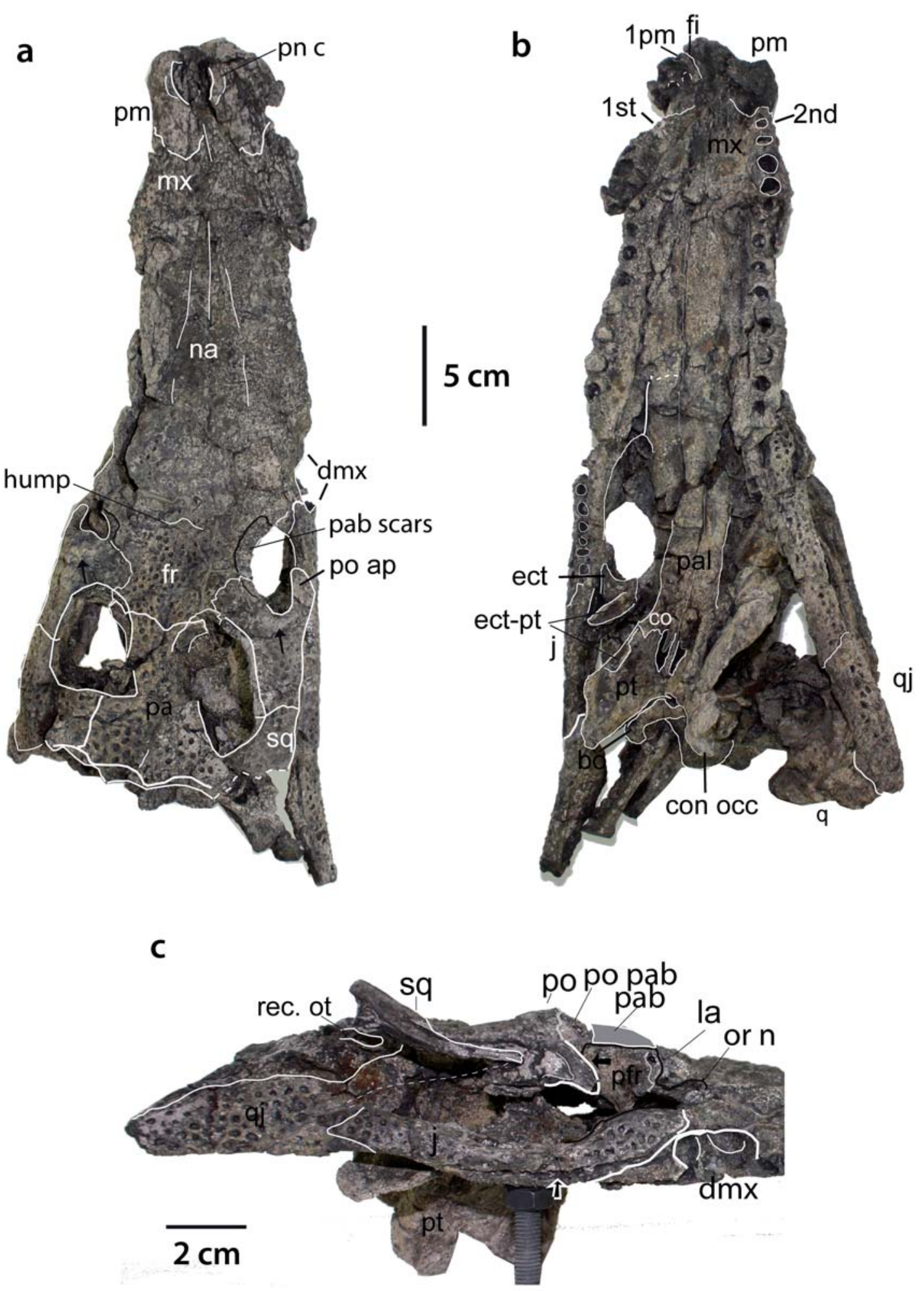

Figure 5. Specimen AR-1-2045 from Mina Santa María, Ariño (Lower Albian, Escucha Formation, Teruel Province) corresponding to the holotype of Hulkepholis plotos sp. n. a) Dorsal view. b) Ventral view. c) Detail of the left periorbital region and skull table in lateral view. Notice that the profile of the prefrontal palpebral (pab, in grey) has been reconstructed, connecting the lachrymal knob and the postorbital palpebral (po pab). The black arrow points the anterior process of the postorbital palpebral underlying the postorbital tuberosity. The white arrow points the sulcus of the jugal. Note: see text for abbreviations. 
anteromedial process that contacts the frontal at the skull table. The fronto-parietal suture at the intertemporal bar is anteriorly placed and its dorsal mid tip is backwardly directed. The postorbital connects the parietal at the supratemporal fossa. The parietals are almost fused. The AR-1-2045 specimen differs from the other Ariño goniopholidids in having a rather short posterolateral squamosal lobe ending in rounded boss. The lobe is backwardly oriented.

The infratemporal fenestra is long in comparison with AR-1-3422. The jugal has short anterior and posterior processes. In lateral view, the ventral margin of the jugal is sulcated. Posterior to the orbit the jugal has a polygonal transverse section with its dorsal surface thick and smooth. The bar is inset at the jugal. Jugal sutures quadratojugal anterior to the infratemporal posterior corner with an almost vertical suture that projects a short ventral process, so that the quadratojugal becomes a long bone. The lateral edge of the cranial table has a median groove that divides the dorsal ornamented surface from the smooth lateral surface. The squamosal projects in an anterior long process that reaches the base of the postorbital bar. The postorbital has a prominent lateral expansion overlying the squamosal. There is a quadratojugal spine. The left otic recess is visible, leaving its caudal margin backwardly open into a partially preserved sulcus.

The occipital region is characterized by its relative height (Fig. 4b). The basioccipital has pendulous tubera, the lateral tubera are ventral to the Eustachian notch. The pterygoid extends ventrally at least twice as long as the basituberal length. The cranioquadrate passage is placed lateral at the paraoccipital process. The quadrate has a prominent twisted medial condyle, and its medial surface steps ventrally. This articulation is mediolaterally expanded, and the ratio between quadrate articulation width and the mid occipital width is 1.8 , and wider than the mid rostral width at the suborbital fenestra. 2011

Genus Anteophthalmosuchus Salisbury \& Naish,

Anteophthalmosuchus escuchae sp. n.

(Figs 4c, 6-9; Table 1)

Derivatio nominis. Dedicated to Escucha Formation.

Holotype. AR-1/37, a partial skeleton deposited at Museo Aragonés de Paleontología/Fundación Conjunto Paleontológico de Teruel-Dinópolis (Teruel, Spain), composed by a disarticulated but associated skull (AR-11097, including the mandible), 11 isolated teeth (AR-11051, AR-1-1096, AR-1-1106 to AR-1-1109, AR-1-1140, AR-1-1167 to AR-1-1169), 17 vertebrae (AR-1-1187, AR-1-1191, AR-1-1192, AR-1-1198 to AR-1-1205, AR1-1340, AR-1-1342, AR-1-1343, AR-1-1345, AR-1-1347,
AR-1-1351, AR-1-1355), 6 ribs (AR-1-1193, AR-1-1194, AR-1-1335, AR-1-1337, AR-1-1339, AR-1-1341), a limb bone (AR-1-1095), and 16 dermal armor plates (AR-11043, AR-1-1047 to AR-1-1049, AR-1-1098, AR-1-1160, AR-1-1165, AR-1-1195, AR-1-1196, AR-1-1346, AR-11348 to AR-1-1350, AR-1-1352 to AR-1-1354).

Diagnosis. Anteophthalmosuchus escuchae differs from Anteophthalmosuchus hooleyi in the palatine-maxillary suture anteriorly convex and longer than wider; the caudal inclination of the mandible, and angular forming the posterior mandibular contour, laterally occupying one third of the mandible height.

Type locality. Site AR-1, Mina Santa María, Ariño, Teruel Province, Spain.

Stratigraphical distribution. Middle Interval with Coal, Lower Sedimentary Succession, Escucha Formation (Rodríguez-López et al., 2009), Lower Albian (Alcalá et al., 2012, Tibert et al., in press.).

\section{Description.}

\section{Skull}

The skull AR-1-1097 is related to the "Hooleyspecimen" (Andrade \& Hornung, 2011) that has been recently described as Anteophthalmosuchus hooleyi by Salisbury \& Naish (2011). The rostral ornamentation is dense and organized with a uniform pattern of regular subcircular pits (Fig. 6). The maxilla is ornamented with radiating ridges at its jugal and lachrymal contact. The maxilla has more than 14 teeth $\left(4^{\text {th }}\right.$ and $5^{\text {th }}$ teeth being the largest), with two lateral waves at the level of the $6^{\text {th }}$, and at the $11^{\text {th }}$ tooth. The lateral margin of the maxilla has a simple band over the alveolar border (Fig. 7). The specimen preserves the anteromedial contour of the orbit, which is deprived of crests. The anterior jugal suture is narrow and ends in an acute, narrow triangular process. The maxillary depression is not preserved, although at that level the maxilla lacks ornamentation; nasals are partially preserved. They broaden with a convex lateral contour posteriorly.

In ventral view the maxilla preserves pits of reception for mandibular teeth, which are placed at the interalveolar spaces from $9^{\text {th }}$ to $12^{\text {th }}$ alveoli. The interalveolar spaces are wide, being maximal at the $10^{\text {th }}$ and $11^{\text {th }}$. The maxilla holds a posterolateral process that enters the suborbital (palatal) fenestra although its medial contour is obscured. The palatine anterior process surpasses anteriorly the palatal fenestra, and has a rounded convex edge. This suture is different in Anteophthalmosuchus hooleyi with a subrectangular palatine suture. The ventral surface of the portion comprising the posterior part of the skull preserves a medial depression at the postorbital in where 

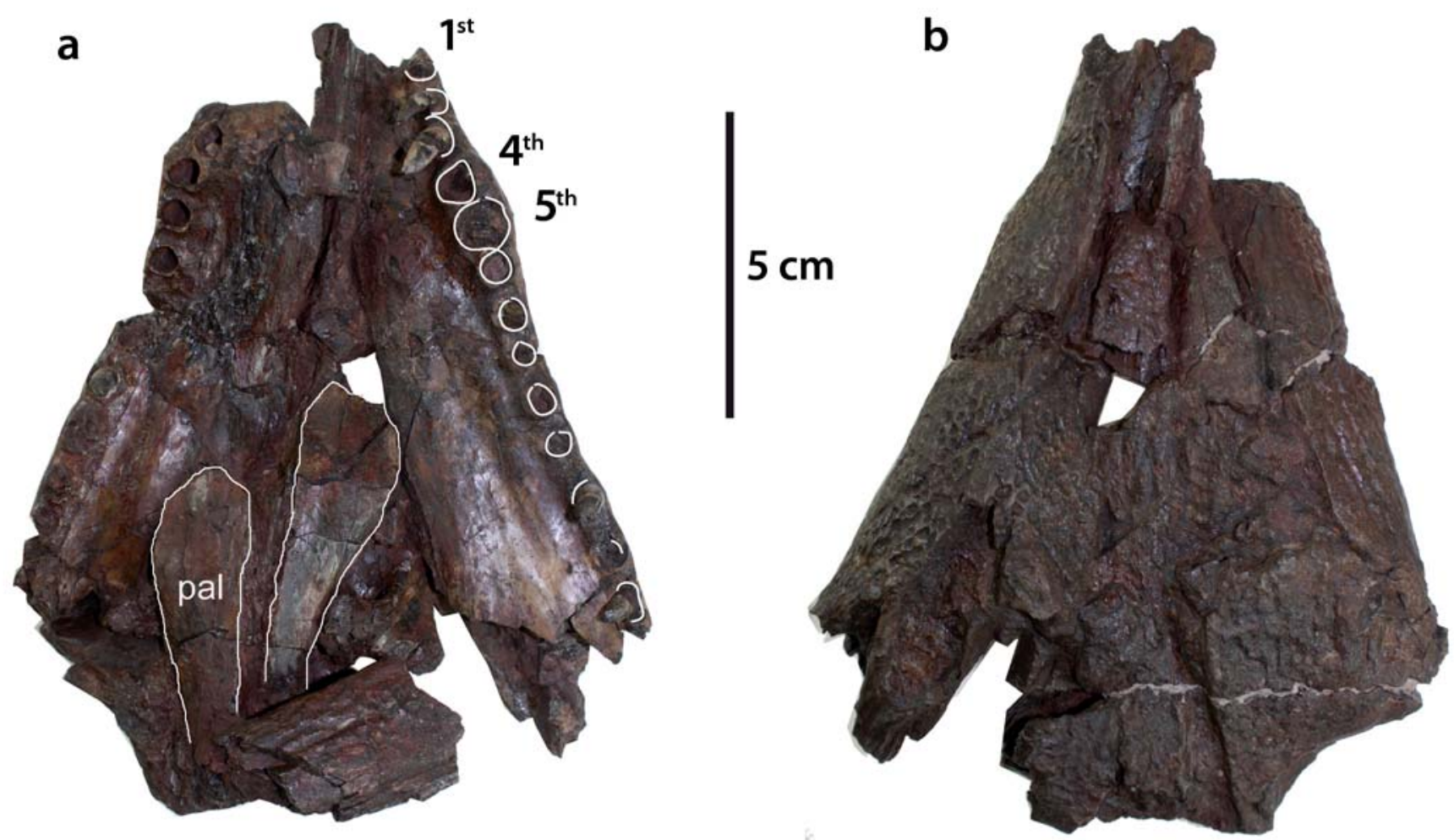

Figure 6. Specimen AR-1-1097 from Mina Santa María, Ariño (Lower Albian, Escucha Formation, Teruel Province) corresponding to the holotype of Anteophthalmosuchus escuchae sp. n. a) Rostral fragment in ventral view. b) Rostral fragment in dorsal view. Note: see text for abbreviations.

the laterosphenoid head contacts, and the area where the bar sets (Fig. 8). In ventral aspect, the relative short length of the jugal, its polygonal cross section, and the suture with the ectopterygoid becomes visible. The ectopterygoid has an acute posterior extension. The quadratojugal projects with strong process that reaches the tip of the dorsal postorbital bar medially and laterally, and contacts with the postorbital anterior projection. A large medial Eustachian opening is visible. The suture between the basisphenoid and basioccipital divides this opening. The quadrate ventral surface exhibits its suture with the pterygoid (Fig. 8), and a developed crest $\mathrm{B}$ that posteriorly ends into a reticulate area as occurs in G. baryglyphaeus. Between crests B and A there the surface is deeply concave.

An isolated left quadrate exposed the cranioquadrate sulcus (Fig. 8). The quadrate forms the ventral floor of the otic recess. Lateral to the otic recess a preotic foramen is exposed. Caudally the quadrate has two sulci, one laterally exposed directed to the preotic foramen, and a second medial one directed to the external otic recess. This medial sulcus ends in a dorsal posterior foramen. Both sulci are separated by a dorsal elevation of the quadrate. The ventral lamina of the squamosal and the paraoccipital process sutures are medially to both sulci.
The skull table is characterized by a wide supratemporal fossa, with a curved lateromedial margin. The skull table has lateral and anterior bars lesser to subequal to the intertemporal bar. The squamoso-postorbital suture divides the cranial table in two unequally portions being the postorbital longer than the squamosal. The squamosal posterior corner is prominent and is projected caudally more than laterally. The frontal forms an oblique, anterolaterally directed suture with the postorbital. The postorbital forms a concave cup forming the posterior orbital wall. A long and sharp postorbital anterolateral spine shields laterally the orbit. This spine is dorsally ornamented. The dorsal base of the postorbital bar extends anteroposteriorly, and has a lateral tubercle.

The infratemporal area occupies half the skull table length (Fig. 7). The jugal is subequally wide at its anterior and posterior edges. Laterally the jugal is profusely ornamented, at the infratemporal area. As in the other specimens it has a smooth dorsal edge posterior to the jugal dorsal process. Posteriorly, the jugal contacts the quadratojugal anterior to the posterior infratemporal corner in a dorsally flexed but caudally long suture. In lateral view, the squamosal anterolateral process ends quite posterior to the postorbital bar. The lateral edge of the skull 


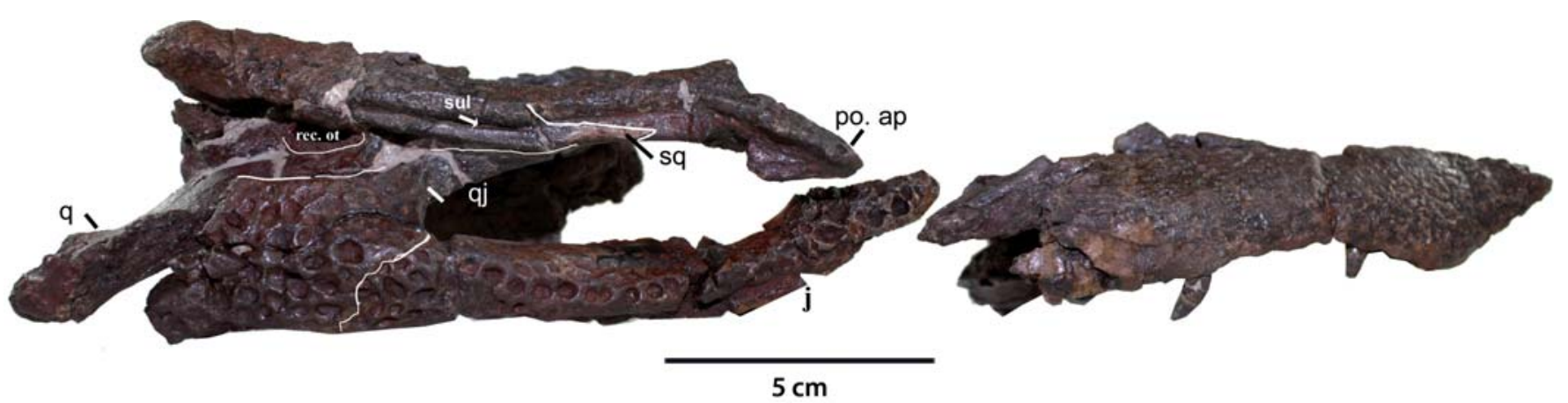

Figure 7. Specimen AR-1-1097 from Mina Santa María, Ariño (Lower Albian, Escucha Formation, Teruel Province) corresponding to the holotype of Anteophthalmosuchus escuchae sp. n. Skull table in lateral view, right side, and rostral fragment in lateral view. The rostral fragment has been rotated in order to show the general lateral aspect of the skull, although it corresponds with the left lateral aspect. Note: see text for abbreviations.

table is smooth and separated by a deep sulcus from its dorsal ornamented part. The sulcus extends from the otic region to the postorbital region, including the prominent anterior extension of the postorbital corner.

The occipital area is characterized by a laterally enlarged basioccipital (Fig. 4c), and occipital condyle. The occipital condyle protrudes caudally surpassing the basioccipital tubera posterior contour. The occipital condyle diameter is diminished, and as described for Anteophthalmosuchus hooleyi the foramen magnum opening is otherwise laterally widen. The quadrate articulation has a twisted medial condyle and its medial surface gently slopes from the dorsal plane. The dorsal quadrate surface has two foramina aereum (Fig. 4c). The ratio between quadrate articulation width and the mid occipital width is 2.8 .
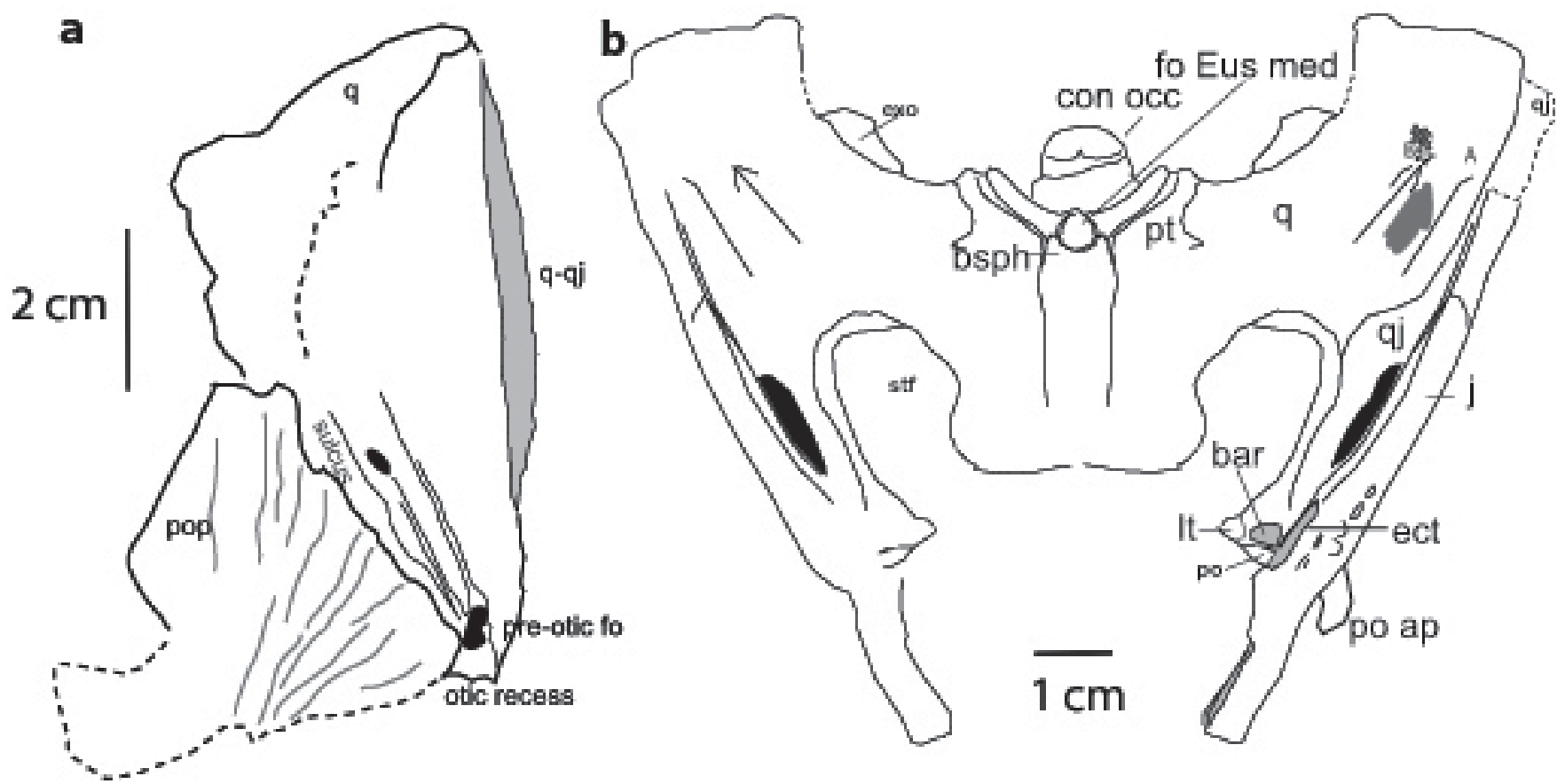

Figure 8. Schematic interpretation of the specimen AR-1-1097 from Mina Santa María, Ariño (Lower Albian, Escucha Formation, Teruel Province) corresponding to the holotype of Anteophthalmosuchus escuchae sp. n. a) Isolated left quadrate in dorsal view showing the interpretation of the otic area and the sulcus of the cranio-quadrate passage (s cqp). b) Ventral view of the posterior skull fragment. Note: see text for abbreviations. 


\section{Mandible}

The posterior part of the mandible differs from $G$. baryglyphaeus and G. simus in several features. The posterior part is profusely ornamented with pits $3 \mathrm{~mm}$ wide (Fig. 9). The posterior border of the mandible is inclined, and the angular reaches the retroarticular process ventrally, while the surangular is laterally placed at this area. It has no external fenestra but a longitudinal long suture between the angular and surangular.
The surangular is longitudinally short. It projects with a dorsal spine reaching the tooth row, while the dentary project a posterior acute forked process. The process is visible in lateral view. At that level the dentary $(30 \mathrm{~mm})$ is low in contrast with the posterior mandibular height $(70 \mathrm{~mm})$. At the inner side the surangular shows a wide sutural contact with the splenial. The dorsal border of the surangular is straight and medially thick.

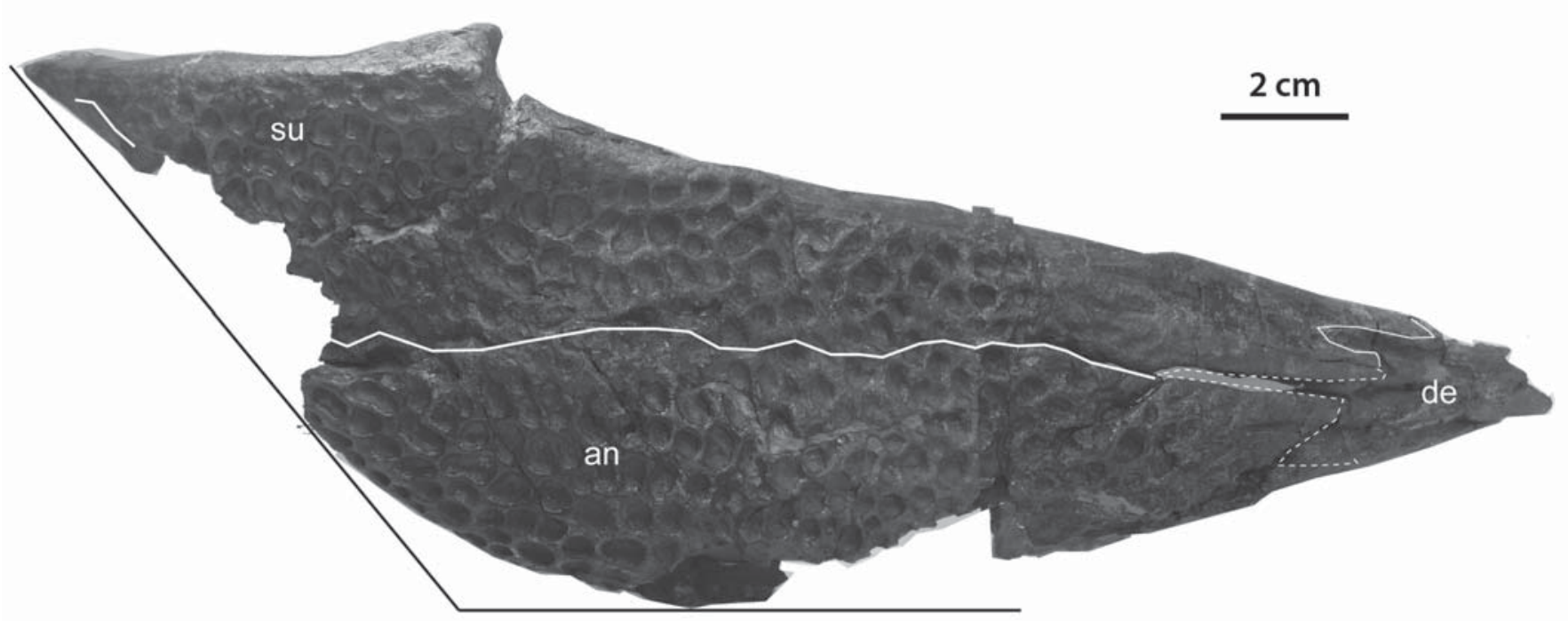

Figure 9. Specimen AR-1-1097 from Mina Santa María, Ariño (Lower Albian, Escucha Formation, Teruel Province) corresponding to the holotype of Anteophthalmosuchus escuchae sp. n. Right mandible in lateral view. Note: see text for abbreviations.

The retroarticular process has a horizontal profile slightly elevated from the dorsal mandibular margin. The retroarticular process is very long (about mid length of the surangular). It is medially curved (although preservation may enhance this feature). It has a sharp medial lamina that extends from the glenoid medial surface with a straight edge but curves posteriorly toward the tip. The retroarticular dorsal surface is deeply concave. Laterally it contacts with the surangular that at that level is thick. The tip of the retroarticular process does not deflect either dorsally not caudally as in $G$. simus. The glenoid area is placed ventrally to the retroarticular process, and faces cranially instead of dorsally. The glenoid bears two cotylar surfaces divided by an oblique ridge that projects medially. The ridge ends in a tubercle that forms the anteromedial border of a convex medial edge. The medial cotyle is shorter than the lateral one but deeper. The posterodorsal rim of the glenoid articulation has a mid rim. The ventral process of the articular shows a continuous sutural area with the surangular and inset in the ventral angular recess.

\section{DISCUSSION}

The European goniopholidids are composed by the three species G. baryglyphaeus, G. simus and G. kiplingi subsumed in the genus Goniopholis, plus a sister clade that includes Hulkepholis (=Goniopholis) willetti (for the "Hulke-specimen"), Anteophthalmosuchus (for the "Hooley-specimen", A. hooleyi), and the "Dollo-specimen" (Andrade et al., 2011; Salisbury \& Naish, 2011). The biochronological interval of the Goniopholis clade spans from the Kimmeridgian to the Berriasian, while its sister group was known from the Valanginian to the Aptian. The Ariño Lower Albian assemblage is therefore the latest identifiable record of the Goniopholididae (Fig. 10). The Iberian fossil record supports the basal dichotomy in the evolution of Goniopholididae because the Ariño goniopholidids share the apomorphies related to the latest members of this family (see Section 3). Furthermore, the Ariño specimens contribute to a better understanding of the clade with preserved postcranial elements in association, 


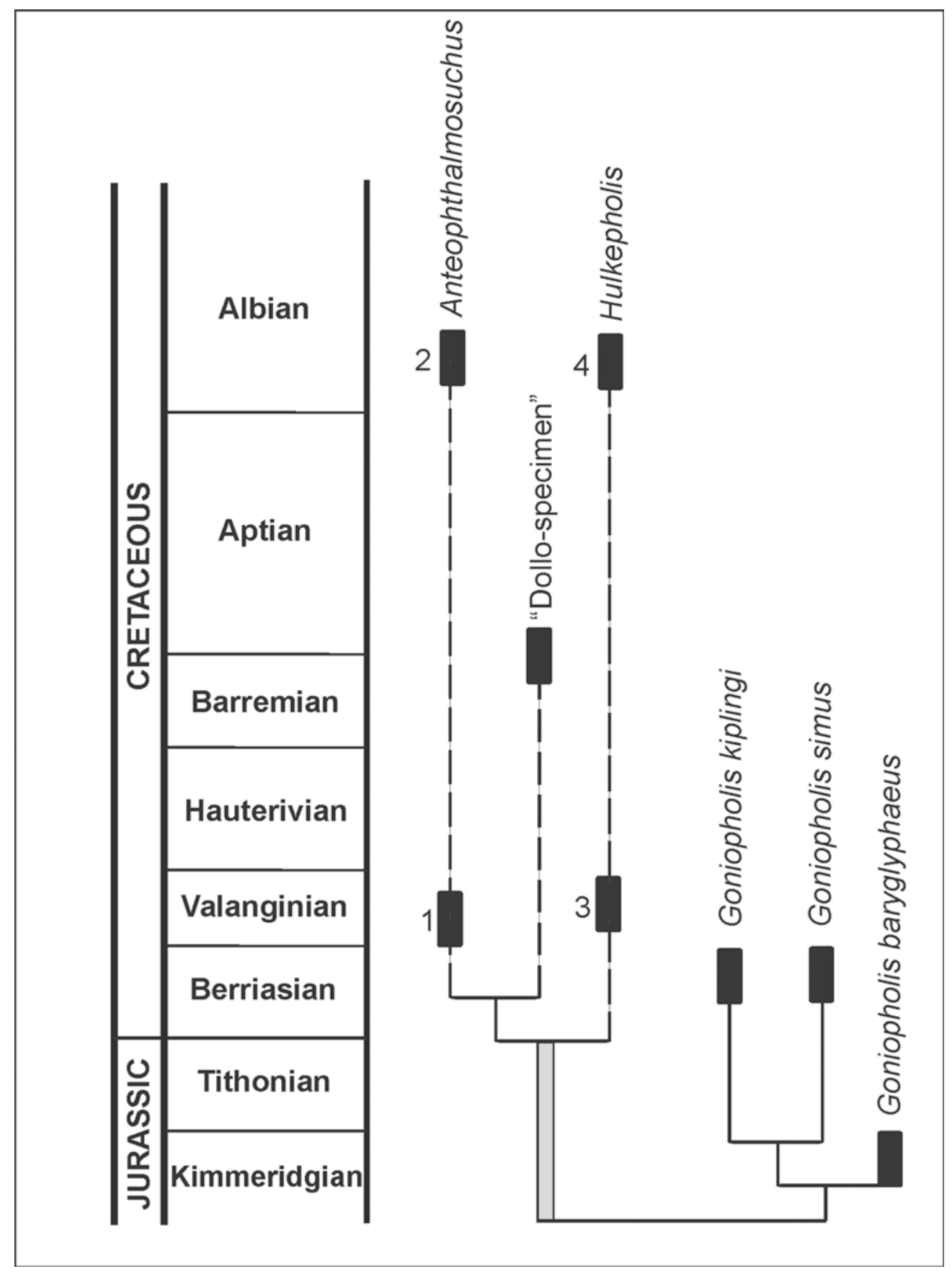

Figure 10. Calibrated cladogram showing the basal dichotomy of the two European clades, according to Andrade et al. (2011). Box in grey remarks the time interval delimiting a potential ghost linage. 1. Anteophthalmosuchus hooleyi, 2. Anteophthalmosuchus escuchae, 3. Hulkepholis willetti, and 4. Hulkepholis plotos. The presence of Goniopholis simus is expected to be expanded in the Cretaceous.

and skull features not clear or not exposed previously on the southern England holotypes of Anteophthalmosuchus hooleyi (i.e., the quadrate configuration, and the mandibular retroarticular region) and "Goniopholis" willetti (i.e., periorbital region), that could be currently attributed to the new genus Hulkepholis.

Ariño skulls AR-1-3422 and AR-1-1097, apart of the medium sized rostral length, have strong phenotypic similarities. They share the features of the clade Anteophthalmosuchus hooleyi + "Dollo-specimen" (Andrade et al., 2011): dorsal component of the orbit; shape of the supratemporal fossa, nasopharyngeal duct sulcate. Not all the synapomorphies diagnosing this group (see Section 3) can be fully tested in the two Ariño individuals (even some as relevant as the long and robust condition of the preorbital anterolateral process shielding 
the orbit) mainly due to preservation. Despite that, AR1-1097, the worst preserved, has the same combination of traits than Anteophthalmosuchus hooleyi (Salisbury \& Naish, 2011), while AR-1-3422 bears the remaining traits diagnosing the clade: prefrontal very long reaching the posteromedial borders of the orbit; jugal only forms a narrow band of bone below the orbit; palpebrals small and rectangular.

According to the diagnosis provided by Salisbury \& Naish (2011) for Anteophthalmosuchus hooleyi, the Ariño and Wessex specimens share: i) the sculpture of the cranial table, infratemporal and rostral areas with regular and wide pits, ii) the lateral bowed process of the postorbital encircling the orbit, iii) the occipital condyle width lesser than the foramen magnum, iv) the absence of a mandibular fenestra, v) the greater length of the postorbital at the dorsal cranial table, vi) the short lateral squamosal projection that does not reach the postorbital bar. Differences confirming the newly described species Anteophthalmosuchus escuchae are based on: the shape of the palatine-maxillary suture, anteriorly convex and longer than wider in $A$. escuchae but subquadrangular in A. hooleyi; the caudal inclination of the mandible in A. escuchae instead of orthogonal, and the disposition of the angular forming the posterior mandibular contour, and laterally occupying one third of the mandible height in A. escuchae.

There are some differences between the specimens AR1-3422 and AR-1-1097, based on the squamosal-postorbital lateral suture, the shape of the jugal-quadratojugal suture, and the diameter and disposition of the occipital condyle. In the light of these differences we tentatively suggest that Ariño AR-1-3422 could be considered a distinct species from A. escuchae. However, AR-1-3422 should be first compared with the "Dollo-specimen" for its definitive determination.

The specimen AR-1-2045 clearly differs from AR-13422 and AR-1-1097 in its longirostral configuration, and periorbital region (with a triangular and wide palpebral). The specimen AR-1-2045 is herein related to Hulkepholis willetti (= Goniopholis willetti), based on the diagnosis provided for this species (Salisbury \& Naish, 2011). They share: i) a long and narrow rostrum, ii) a similar premaxillary tooth arrangement being the $5<4<3<2$, iii) an interorbital hump, iv) the squamosal tip with a rounded and short boss, v) a large and triangular palpebral, vi) the frontal exclusion at the orbital contour, viii) almost fused parietals, ix) postorbital as long as the squamosal. We herein described the new species Hulkepholis plotos, which differs from $H$. willetti in the posterior position of the choana, the pendulous basioccipital, and development of the anterolateral projection of the postorbital affected by the extension of the palpebral underlying the postorbital anterior tuberosity, and by the lateromedially expanded quadrate articulation of the Ariño species. The absence of a postorbital palpebral might be due to preservation in the Wessex specimen, a condition that should be confirmed.

We have proposed the new genus Hulkepholis based on the phylogenetic dichotomy of the two European clades (Fig. 10). Both clades are robustly supported according to Andrade et al. (2011), and all of the Ariño specimens support this evolutionary divergence. Nonetheless, two of the synapomorphies that diagnose the Goniopholis sensu stricto species are shared by Anteophthalmosuchus hooleyi (i.e., anterior face of the palatal process truncate with a transverse suture, see Salisbury \& Naish, 2011, fig. 24.7 , p. 320), and $A$. escuchae (i.e., absence of external mandibular fenestra, note that $G$. simus has an external mandibular fenestra according to Salisbury et al., 1999). The expectation of validating the monophyletic status of the genus Goniopholis will require the inclusion of the Ariño species in a further phylogenetic analysis.

The Latest Hauterivian to Early Albian rifting phase of the Iberian basin was associated with a major transgression episode that was interrupted by a short-lived early Aptian regression and terminated by the mid Albian regression. These regressions resulted in the progradation of deltaic complexes that linked to some tectonic processes, generating during mid Albian the accumulation of thick deltaic and lacustrine successions such as the coal bearing Escucha Formation (Martín-Chivelet, 2002). The stratigraphical and sedimentological analyses of Ariño, where the bonebeds have been found, indicate a sedimentary coastal system with barrier islands and marshes (Rodríguez-López et al., 2009). The coal layers were produced in back-barrier marshes associated with a barrier-lagoon system; at that environmental system two ecomorphotypes of crocodyliforms concurred: Hulkepholis plotos as a long-snouted species, and a second species with a moderate wide and medium sized rostrum. Populations of sympatric recent species occupy either different niches (habitat partitioning) or exploit recourses according to time partitioning (see Salisbury \& Naish, 2011 for profuse examples). The longirostral $H$. plotos might be considered as an active aquatic predator, based on its rostral shape and homodonty. The occurrence of species related to Anteophthalmosuchus hooleyi and Hulkepholis willetti reflects similarities between the neosuchian assemblage of Ariño and the Wessex-Weald basin of southern England never reported before. In addition, if AR-1-3422 were related to the goniopholidid species from Bernissart (Belgium) a further indication of geographical connection between these areas should be undertaken. 


\section{ACKNOWLEDGEMENTS}

The authors dedicate this article to Dr Nieves López Martínez, always surprised on the complex taxonomy of the family Goniopholididae. She was at the PhD Committee of ADB in 1986, and one of her questions was: Why aren't you able to provide a clear specific determination on the Goniopholis material? Probably, ADB should answer that she's not yet capable! Dr Nieves López Martínez was the advisor of the $\mathrm{PhD}$ of LAM and he will forever remember how fast she identified wrong taphonomic approaches. We would like to thank the editor Dr Francisco Javier Rodríguez-Tovar and guest co-editor Dr Manuel Hernández Fernández; reviewers Dr Daniela Schwarz-Wings and Dr Felipe C. Montefeltro, for their valuable comments on the manuscript; and Dr Carmen Gallardo for advise us in the Greek grammar. We appreciate the ongoing collaboration for this research of SAMCA Group staff, especially its president and Ariño-based members. This study is part of the palaeontology research projects of the Departamento de Educación, Universidad, Cultura y Deporte, Gobierno de Aragón, and has been supported by its Dirección General de Patrimonio Cultural (exp. 201/2010, 201/102011, 201/10-11-2012), Project CGL2009-11838BTE and DINOSARAGÓN CGL2009-07792BTE R\&D Project (Ministerio de Ciencia e Innovación and FEDER Funds), FOCONTUR (Grupo de Investigación Consolidado E-62, Departamento de Industria e Innovación, Gobierno de Aragón and Fondo Social Europeo), Instituto Aragonés de Fomento, Fundación SAMCA, and Fundación Conjunto Paleontológico de Teruel-Dinópolis. We thank all our Fundación's colleagues who excavated in Ariño and prepared the fossils in the laboratory.

\section{REFERENCES}

Alcalá, L., Espílez, E., Mampel, L., Kirkland, J.I., Ortiga, M., Rubio, D., González, A., Ayala, D., Cobos, A., RoyoTorres, R., Gascó, F. \& Pesquero, M.D. 2012. A new Lower Cretaceous vertebrate bonebed near Ariño (Teruel, Aragón, Spain); found and managed in a joint collaboration between a mining company and a palaeontological park. Geoheritage, 4, 275-286.

Andrade M.B. \& Hornung J.J. 2011. A new look into the periorbital anatomy of Goniopholis (Mesoeucrocodylia, Neosuchia) and related forms. Journal of Vertebrate Paleontology, 31, 352-368.

Andrade, M.B., Edmonds, R., Benton, J.A. \& Schouten, R. 2011. New Berriasian species of Goniopholis (Mesoeucrocodylia, Neosuchia) from England, and a review of the genus. Zoological Journal of the Linnean Society, 163, 66-108.

Benton, M.J. \& Clarck, J.M. 1988. Archosaur phylogeny and the relationships of the Crocodilia. In: The phylogeny and classification of tetrapods. 1: Amphibians, reptiles, birds (ed. Benton, M.J.). Systematics Association, Special Volume, 35A. Clarendon Press, Oxford, 295-338.

Brinkmann, W. 1992. Die Krokodilier-Fauna aus der UnterKreide (Ober-Barremium) von Uña (Provinz Cuenca, Spanien). Berliner Geowissenshaftliche Abhandlungen, E (5): 1-123.

Buscalioni, A.D. 1986a. Los cocodrilos fósiles del registro español. Paleontologia i Evolució, 20, 93-98.

Buscalioni, A.D. 1986b. Cocodrilos fósiles del registro español. Analisis Sistemático y Fiologenético de la Familia Atoposauridae. $\mathrm{PhD}$ Thesis, Facultad de Ciencias. Universidad Autónoma de Madrid, Madrid.

Buscalioni, A.D \& Sanz, J.L. 1987. Cocodrilos del Cretácico inferior de Galve (Teruel, España). Estudios Geológicos, vol. extr. Galve-Tremp, 23-43.

Buscalioni, A.D., Fregenal-Martinez, M.A., Bravo, A., Poyato-Ariza, F.J. Sanchiz, B., Baez, A.M., Cambra-Moo, O., Martín-Closas, C., Evans, S.E. \& Marugán-Lobón, J. 2008. The vertebrate assemblage of Buenache de la Sierra (Upper Barremian of Serranía de Cuenca, Spain) with insights into its Taphonomy and Palaeoecology. Cretaceous Research, 29 (4), 687-710.

Cope, E.D. 1875. Check-list of North American Batrachia and Reptilia with a systematic list of the higher groups and an essay on geographical distribution based on the specimens in the U.S. National Museum. Bulletin of the United States National Museum, 1, 1-104.

Crespo, E.G. 2002. Paleoherpetofauna Portuguesa. Revista Española de Herpetología, 17-35.

Cuenca-Bescós, G., Amo, O., Barco, J.L., Canudo, J.I., Royo, R. \& Ruiz-Omeñaca, J.I. 1999. The Tithonian (Upper Jurassic)-Barremian (Lower Cretaceous) vertebrates from Galve (Teruel, Spain). In: IV European Workshop on Vertebrate Palaeontology (eds. Canudo, J.I. \& CuencaBescós, G.). Universidad de Zaragoza, Zaragoza, 101114.

Díaz Molina, M. \& Yébenes, A. 1987. La sedimentación litoral y continental durante el Cretácico inferior. Sinclinal de Galve, Teruel. Estudios Geológicos, vol. extr. GalveTremp, 3-21.

Fuentes-Vidarte, C., Meijide-Calvo, M., Meijide Fuentes, J. \& Meijide Fuentes, M. 2003. Fauna fósil del yacimiento Mesozoico (Cretácico Inferior, Wealdiense de los Caños), (Soria, España). De Celtiberia, 97, 487-506.

Gasulla, J.M., Ortega, F., Escaso, F. \& Pérez-García, A. 2011. Los yacimientos de vertebrados de la Formación Arcillas de Morella (Aptiense inferior). In: Viajando a mundos pretéritos (eds. Pérez-García, A., Gascó, F., Gasulla, J.M. \& Escaso, F.). Ayuntamiento de Morella, Morella, 157-171.

Hulke, J.W. 1878. Note on the two skulls from the Wealden and Purbeck formations indicating a new subgroup of Crocodilia. Quarterly Journal of the Geological Society, $34,377-382$

Leduc, T. 2012. Diagenesis of the fossil bones of Iguanodon bernissartensis from the Iguanodon sinkhole. In: Bernissart Dinosaurs and Early Cretaceous Terrestrial 
Ecosystems. Part 1, New investigations into the Iguanodon sinkhole at Bernissart and other Early Cretaceous localities in the Mons Basin (Belgium) (ed. Godefroit, P.). Indiana University Press, 113-135.

Martín-Chivelet, J. (coord.) 2002. Cretaceous. In: The Geology of Spain (eds. Gibbons, W \& Moreno, T.). The Geological Society, London, 255-292.

McDonald, A.T., Espílez, E., Mampel, L., Kirkland, J.I. \& Alcalá, L. 2012. An unusual new basal iguanodont (Dinosauria: Ornithopoda) from the Lower Cretaceous of Teruel, Spain. Zootaxa, 3595, 61-76.

Ortega, F., Moratalla, J.J., Buscalioni, A.D., Sanz, J.L., Jiménez, S. \& Valbuena, J. 1996. Sobre la presencia de un cocodrilo fósil (Crocodylomorpha: Neosuchia: Goniopholis sp.) en la Cuenca de Cameros (Cretácico inferior: Vadillos-San Román de Cameros, La Rioja). Zubia, 14, 113-120.

Owen, R. 1842. Report on British fossil reptiles, part II. Reports of the British Association for the Advancements of Sciences, 11, 60-204.

Pouech, J. 2008. Position des mammifères dans les écosystèmes mésozoïques d'Europe occidental: le site de Chevresde-Cognac (Berriasien, Charente, France). $\mathrm{PhD}$ Thesis, Université Claude Bernard, Lyon-1, Lyon.

Puértolas-Pascual, E., Moreno-Azanza, M. \& Canudo, J.I. 2012. Primer registro de un cocodrilomorfo (Neosuchia, Goniopholididae?) en la Formación Escucha (Albiense inferior) de la mina Corta Barrabasa (Teruel). $X X$ Encuentro de Jóvenes Investigadores en Paleontología, Sot de Chera, Valencia, 94-96.

Rodríguez-López, J.P., Meléndez, N., Soria, A.R. \& de Boer, P.L. 2009. Reinterpretación estratigráfica y sedimentológica de las formaciones Escucha y Utrillas de la Cordillera Ibérica. Revista de la Sociedad Geológica de España, 22, 163-219.

Ruiz-Omeñaca, J.I., Canudo, J.I., Aurell, M., Bádenas, B., Barco, J.L., Cuenca-Bescós, G. \& Ipas, J. 2004. Estado de las investigaciones sobre los vertebrados del Jurásico Superior y Cretácico Inferior de Galve (Teruel). Estudios Geológicos, 60, 179-202.

Salisbury, S.W. 2002. Crocodilians from the Lower Cretaceous (Berriasian) Purbeck Limestone Group of Dorset, Southern England. In: Life and environment in Purbeck times (eds. Milner, A.R. \& Batten D.J.). Special Papers in Palaeontology, 68, 121-144.

Salisbury, S.W. \& Naish, D. 2011. Crocodilians. In: English Wealden Fossils (ed. Batten, D.J.). The Palaeontological Association, London, 305-369.

Salisbury, S.W., Willis, P.M.A., Peitz, S. \& Sander, P.M. 1999. The crocodilian Goniopholis simus from the Lower Cretaceous of north-western Germany. Special Papers in Paleontology, 60, 121-148.

Sánchez-Hernández, B., Benton, M.J. \& Naish, D. 2007. Dinosaurs and other fossil vertebrates from the Late Jurassic and Early Cretaceous of the Galve area, NE Spain. Palaeogeography, Palaeoclimatology, Palaeoecology, 249 (1-2), 180-215.

Sastre García, A. 2007. Caracterización de morfotipos dentarios de cocodrilos en el Cretácico Inferior de Morella (Castellón). IV Jornadas Internacionales sobre Paleontología de Dinosaurios y su Entorno, Salas de los Infantes, Burgos, 87-89.

Schwarz, D. 2002. A new species of Goniopholis from the Upper Jurassic of Portugal. Palaeontology, 45(1), 185208.

Steel, R. 1973. Crocodylia. In: Handbuch der Paläoherpetologie, Teil 16 (ed. Kuhn, O.). Gustav Fisher Verlag, Stuttgart, $1-116$.

Tibert, N.E., Colin, J.P., Kirkland, J.I., Alcalá, L. \& MartínClosas, C. in press. Lower Cretaceous Ostracoda from an Escucha Formation Dinosaur Bonebed in Eastem Spain. Micropaleontology. 
